\title{
Modeling of Academic Information System in Higher Education Institution toward Education 3.0: A Literature Review
}

\author{
Hadi Prasetyo Utomo, Abdul Talib bin Bon, and Mokhamad Hendayun
}

\begin{abstract}
Academic information system (AIS) was used by many higher education institutions (HEIs) to help in manage their academic affairs. Most of AIS used only for administrative purposes. With the emergence of Education 3.0 paradigm, the AIS must be support its characteristics. Education 3.0 characteristics involve learning and administrative purposes. Based on previous related studies, this research found that AIS must support learning purpose by integrating existing AIS with e-learning. The AIS also must support parents and industry involvement. To accommodate all new features above, the existing AIS must transform by following certain guide. A model needs to guide the transformation and Substitution Augmentation Modification Redefinition (SAMR) framework can be used for modeling.
\end{abstract}

Index Terms-Academic information system, education 3.0, higher education institution, modeling, SAMR.

\section{INTRODUCTION}

As part of information system (IS), academic information system AIS was largely implemented in many higher education institutions (HEIs) [1]. They used AIS to help them in manage academic affairs. Most of HEIs only used AIS for administrative purposes [2]. But in the other hand, HEIs also used AIS to support their decisions maker [1]. With current technology, AIS can be used to support another purpose such as Education 3.0.

Education 3.0 was new paradigm in education world [3]. Its characteristics made learning process wider. The role of academic stakeholder has changed. Technology usage more advanced and the learner status also extended [4]. The AIS must be enhanced to support the characteristics.

\section{Methodology}

This research use qualitative method to collect related previous studies and analysis the needs of AIS to support Education 3.0 characteristics. This research will suggest the features must be added to AIS, if HEIs already implemented Education 3.0 paradigm in their learning process.

Manuscript received May 23, 2016; revised December 12, 2016.

H. P. Utomo and A. Talib are with Universiti Tun Hussein Onn Malaysia, Parit Raja 86400, Batu Pahat, Malaysia (e-mail: hp150078@siswa.uthm.my.edu,talib@uthm.my.edu).

M. Hendayun is with Faculty of Engineering, Universitas Langlangbuana, Karapitan Street 40261, Bandung, Indonesia (e-mail: mhendayun@gmail.com).

\section{RESULTS AND DISCUSSION}

\section{A. Academic Information System}

Academic Information System (AIS) is software intended to process the academic data of an educational institution. AIS in higher education institutions (HEIs) are generally used to manage the student academic data starting from registration, plan their study and to look at the study result. Most of HEIs use web-based AIS connected to intranet or internet [2]. The study mentioned the AIS only used for administrative purpose. The users of AIS from this study only student and administration staff.

From [1] study, AIS refer to a set of systems and activities that are used to organize, to process, and to use information as a source within an HEI. The output of the information resulted from this system will deliver information to the leaders or the decision makers that can be categorized in different utilization and different purposes. AIS in this study not only used for administrative purpose, but also used by leaders of institution to help them make a decision for institution development. The AIS used by students, lecturer, administration staff and executive.

An AIS has to cater to the needs of students, faculty and administrative staff [5]. They compare the AIS in three different HEIs. The study found that AIS mostly have same procedure and function. Hence, they also suggested AIS must be flexible to development. This helps the system to remain up to date and provides better functionality with changing technology and needs of the users.

\section{B. Education 3.0}

Education is a complex process. It demands the very best from parents, teachers, students, and administrators collaboration. Technology can help this collaboration. When technology is implemented and integrated appropriately, they have an opportunity to learn about that technology by using it as a part of their learning. This new approach called Education 3.0 [3].

In the class room, Education 3.0 means a rich, collaborative learning experience focused around authentic, project-based learning. Students and teachers should have access to materials, formative assessments and each other "anytime and anywhere," and be able to draw in experts from around their system or around the world at the touch of a button [3].

According to [4], Education 3.0 is characterized by rich, cross institutional, cross cultural educational opportunities within which the learners themselves play a key role as 
creators of knowledge artifacts that are shared, and where social networking and social benefits outside the immediate scope of activity play a strong role. The distinction between artifacts, people and process becomes blurred, as do distinctions of space and time.

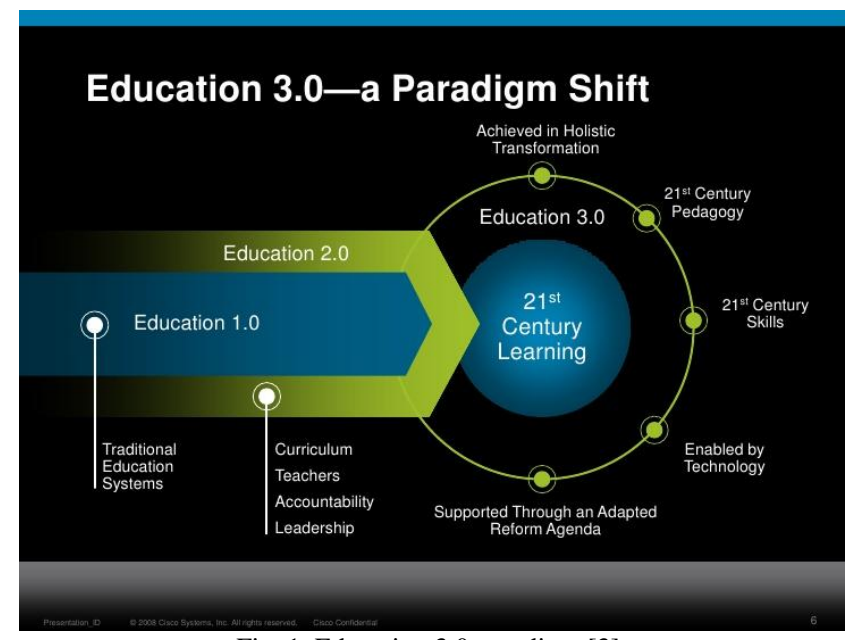

Fig. 1. Education 3.0 paradigm [3].

In Education 3.0, students are empowers to produce, not merely to consume the knowledge [6]. Education 3.0 is made possible by Education 2.0 which is internet-enabled learning, and by centuries of experience with memorization in Education 1.0. Education 2.0 begins the transition to a new educational paradigm based on knowledge production and innovation production, the appropriate engines for viable 21 st century economies. Education 3.0 is qualitatively different incarnations that build upon Education 2.0 information sourcing capabilities and, to a lesser extent, the memorization habits of Education 1.0 [6]. Characteristics of Education 1.0, 2.0 and 3.0 are given in Table I.

According to [7], many education institutions have practiced the principle of Education 3.0 in their learning process. As we can see in Table 2.1, the teaching characteristic in Education 3.0 was more connected with technology. They use e-learning technology to produce and share knowledge. Mostly, HEIs implemented e-learning using ready-to-use application such as Moodle LMS, Edmodo, etc [8]. Those applications not only can support learning activity, but also can support evaluation activity. Assessment, scoring and marking processes are also provided by those applications. However, because those applications are separated from AIS, the evaluation results can not automatically showed in AIS [9]. Teacher/lecturer must input it manually into AIS because most of the HEIs just developed AIS for academic administrative purpose [10]. A study by [9] suggested to integrating AIS and e-learning to simplification processes between both of them. Its mean AIS and e-learning become one application and to do that we cannot use ready-to-use application anymore.

Moodle, Edmodo and others e-learning application have been used by many HEIs [8]. They use the application because it simple to install and already support mobile platform. If we want to build our own integrated AIS with e-learning, we must consider the AIS to support mobile platform. Based on [11] and [12] studies, most of students already have smartphone or tablet PC as their mobile device.
Therefore the integrated AIS must available on mobile platform for better accessibility in learning process [13]. Besides that, the mobile platform provides an ideal avenue for the transfer of tacit knowledge which will now improve the students' absorptive capacity when collaboration is used in the learning process [14].

TABLE I: CHARACTERISTICS OF EDUCATION 1.0, 2.0 AND 3.0 [6]

\begin{tabular}{|c|c|}
\hline & Education \\
\hline $\begin{array}{l}\text { Meaning } \\
\text { is ... }\end{array}$ & Dictated \\
\hline $\begin{array}{l}\text { Technolo } \\
\text { gy is ... }\end{array}$ & $\begin{array}{l}\text { Confiscate } \\
\text { the classro } \\
\text { door (digit } \\
\text { refugees) }\end{array}$ \\
\hline $\begin{array}{l}\text { Teaching } \\
\text { is } \\
\text { done ... }\end{array}$ & $\begin{array}{l}\text { Teacher to } \\
\text { student }\end{array}$ \\
\hline
\end{tabular}

\begin{tabular}{|c|c|c|c|}
\hline & & $\begin{array}{l}\text { Internet } \\
\text { resources are a } \\
\text { normal part of } \\
\text { learning } \\
\text { activities }\end{array}$ & $\begin{array}{l}\text {-people } \\
\text { (co-construction } \\
\text { of knowledge) }\end{array}$ \\
\hline $\begin{array}{l}\text { Schools } \\
\text { are } \\
\text { located } \\
\ldots\end{array}$ & $\begin{array}{l}\text { In a building } \\
\text { (brick) }\end{array}$ & $\begin{array}{l}\text { In a building or } \\
\text { online (brick } \\
\text { and click), but } \\
\text { increasingly on } \\
\text { the Web through } \\
\text { hybrid and full } \\
\text { internet courses }\end{array}$ & $\begin{array}{l}\text { Everywhere in the } \\
\text { "creative society" } \\
\text { (thoroughly } \\
\text { infused into } \\
\text { society: cafes, } \\
\text { bowling alleys, } \\
\text { bars) }\end{array}$ \\
\hline $\begin{array}{l}\text { Parents } \\
\text { view } \\
\text { schools } \\
\text { as ... }\end{array}$ & Daycare & $\begin{array}{l}\text { Daycare with an } \\
\text { laboratory edge, } \\
\text { provided by } \\
\text { open access and } \\
\text { gradual } \\
\text { movement } \\
\text { toward } \\
\text { project-based } \\
\text { learning }\end{array}$ & $\begin{array}{l}\text { Places for students } \\
\text { to create } \\
\text { knowledge, and } \\
\text { for which parents } \\
\text { may provide } \\
\text { domestic, } \\
\text { volunteer, civic, } \\
\text { and fiscal forms of } \\
\text { support }\end{array}$ \\
\hline $\begin{array}{l}\text { Teachers } \\
\text { are ... }\end{array}$ & $\begin{array}{l}\text { Licensed } \\
\text { Professionals }\end{array}$ & $\begin{array}{l}\text { Licensed } \\
\text { Professionals } \\
\text { who team with } \\
\text { students, parents } \\
\text { and others to } \\
\text { (gradually) } \\
\text { create more } \\
\text { interesting class } \\
\text { experiences }\end{array}$ & $\begin{array}{l}\text { Everybody, } \\
\text { everywhere, } \\
\text { backed up by } \\
\text { wireless devices } \\
\text { designed to } \\
\text { provide } \\
\text { information raw } \\
\text { material for } \\
\text { knowledge } \\
\text { production }\end{array}$ \\
\hline $\begin{array}{l}\text { Hardware } \\
\text { and } \\
\text { software } \\
\text { in } \\
\text { schools } \\
\ldots\end{array}$ & $\begin{array}{l}\text { Are purchased } \\
\text { at great cost and } \\
\text { ignored }\end{array}$ & $\begin{array}{l}\text { Are open source } \\
\text { and available at } \\
\text { lower cost, } \\
\text { permitting open } \\
\text { access "on the } \\
\text { cheap" and } \\
\text { beyond school } \\
\text { premises and } \\
\text { time frames }\end{array}$ & $\begin{array}{l}\text { Are available at } \\
\text { low cost and are } \\
\text { used purposively, } \\
\text { for the selective } \\
\text { production of } \\
\text { knowledge }\end{array}$ \\
\hline $\begin{array}{l}\text { Industry } \\
\text { views } \\
\text { graduates } \\
\text { as .... }\end{array}$ & $\begin{array}{l}\text { Line workers } \\
\text { who must be } \\
\text { trained and from } \\
\text { whom little } \\
\text { created is } \\
\text { expected }\end{array}$ & $\begin{array}{l}\text { A workers } \\
\text { marginally or } \\
\text { ill-prepared for } \\
\text { the } \\
\text { knowledge-prod } \\
\text { ucing economy }\end{array}$ & $\begin{array}{l}\text { As } \\
\text { knowledge-produc } \\
\text { ing co-workers } \\
\text { and entrepreneurs } \\
\text { who can support } \\
\text { the development } \\
\text { of focused } \\
\text { knowledge } \\
\text { construction }\end{array}$ \\
\hline
\end{tabular}

Education 3.0

\section{Socially}

constructed and $\begin{array}{ll}\text { with aid of } & \text { contextually } \\ \text { (usually limited) } & \text { reinvented }\end{array}$ $\begin{array}{ll}\text { (usually limited) } & \text { reinvented } \\ \text { Internet access } & \text { knowledge }\end{array}$ Cautiously Everywhere adopted open (digital natives in access (digital a digital universe) immigrants)

for ubiquitous

knowledge construction and transmission Teacher to student, student to student, student to teacher,

student and

student to student (progressivism); people-technology Internet 
Besides support mobile platform, the integrated AIS also must support parent involvement. Considering that most of the time that students spent in HEIs with their lecturers and in home with their parents [15]. In Edmodo, teachers are able to notify parents of their child's progress and provide feedback on how to support continued growth. Parents can also proactively monitor their child's upcoming assignments and ongoing activities to ensure success [16]. Because everyone in Education 3.0 is can be a learner [6], parents can learn from their children academic activity through the integrated AIS and involve to their children education and also give values to their social live.

After parent involvement, there is another stakeholder involves in Education 3.0 characteristics. The characteristic is industry involvement. Mostly, industry and HEIs already collaborated in strategic level such as research, knowledge transfer and curriculum development [17]. But in operational level such as recruitment, the collaboration happen after students graduated. The industry gets information about students' achievement after they graduated [18]. Ideally, industry also can involve in their learning process. Industry can access students' portfolio and achievement during semester, or they can be reviewers in related assignment. With those, industry can select prospective candidates early before they graduated. To do so, the industry must be active in the system, in this case is the integrated AIS.

Based on the facts above, for HEIs that have implemented Education 3.0 characteristics in their learning process are suggested to transform their AIS to support those characteristics. Especially for HEIs that already used e-learning or mobile learning or blended learning and also for those who already implemented student centered learning, the transformation becomes priority.

\section{Modeling of Academic Information System}

AIS is part of information system (IS) and an implemented of information and communication technology (ICT) in HEIs [1]. Continual improvement of IS requires the institutions' positioning with regard to its IT capabilities and the quality of its services. To manage IS, HEIs must have a model as instrument for knowing a better positioning of the organization and help find better solutions for change [19]. Hence, [20] describe that a model can be a basis of an integrated system that overcomes much of the problems as previously stated.

A model should be developed based on the internationally recognized standards and the model could be used as an action guideline for HEIs to change their IS [21]. Both of [19] and [21] studies have proved that a model is an important instrument if the institutions want to change or transform their existing IS.

A study by [10] also mentioned about AIS changes. They created a model to synchronize business process in academic affairs and AIS. They found existing AIS can be more efficient after modeling. They used single case study method for modeling and interview for data collection. They also used Service Oriented Architecture (SOA) and Model Driven Architecture (MDA) as their framework and used Unified Modeling Language (UML) as design tool. UML also used by [22] to analysis function point of AIS in Trisakti
University. Their model scope only support for administrative purpose. However, with its ICT capabilities, their AIS can support more features than new student registration, admission procedure, graduation and data management.

In another study by [20], case study method also used for IS modeling. They collected data from documents, interview and focus group discussion. They created the model to measure learning outcome attainment and then integrated the model into their existing AIS. Same as a research by [1], they did not use AIS for administrative purpose only, but also used it to generate information for the decision maker. However, if their AIS can measure learning outcome attainment, there are more advantages if their AIS can support the learning process too.

Learning process in HEIs always changes time by time. The changes can be in organization, government rules, curriculum, technology or pedagogy. These changes can be affected to learning process. Some HEIs used model to help them in managing changes [19]. Substitution Augmentation Modification Redefinition (SAMR) can be used as a framework to accommodate changes from technology and pedagogy. SAMR was developed to adopt technology in education [23].

A research by [24] used SAMR as a model for supporting curriculum changes in HEI and adopts technology to the changes. They also used single case study method in their research. SAMR also used by [25] to asses ICT pedagogical adoption in HEI. They used Makerere University as case study and found that SAMR could help institutions to integrate technology in their pedagogical process.

\section{Substitution Augmentation Modification Redefinition (SAMR) Framework}

The transformation process of AIS to support the characteristics of Education 3.0 can be guided using a model. Substitution, Augmentation, Modification, Redefinition (SAMR) framework can be chosen for modeling. SAMR was created to adopt technology into education [23].

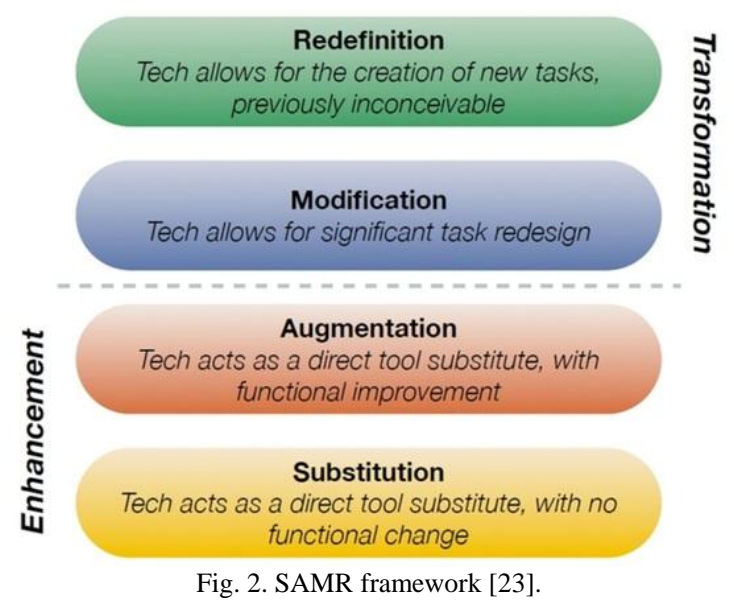

The SAMR describes the use of technology in learning tasks, from the simplest (substitution) to the more complex and innovative ones (redefinition). The SAMR model sees Substitution and Augmentation as ways to enhance learning tasks, whereas Modifications and Redefinition allow for transformation [23]. 
SAMR used by [26] to adopt mobile learning for the language teacher. From the interview with English language teachers, the research found many activities that enable the transformation of traditional classroom tasks through the use of mobile devices. SAMR can be used as a transformation model in education institutions with technology driven.

SAMR used by [27] to evaluate mobile learning in HEI and also reviewed and evaluated research by [26]. They suggested using SAMR to evaluate current technology usage in education. This model could then be used to guide the design and development of future studies.

Research by [25] adopted SAMR to assess ICT pedagogical adoption in HEI. They used Makerere University as case study and found that SAMR could help institutions to integrate technology in their pedagogical process. Their findings also emerged four (4) key areas to help the integration. Those are 1) e-learning unit, 2) skills and knowledge in educational technologies, 3) infrastructure, and 4) educational technology policy.

From the facts above, SAMR used to help integrating technology into education. Most of researches using SAMR already mentioned some characteristics of Education 3.0. However, none research specifically discuss the linkage between Education 3.0 and AIS. Therefore, this research will focus on transformation AIS to support Education 3.0 characteristics and SAMR can be adapted as a transformation model.

\section{CONCLUSION}

Use of ICT in academic management affairs highly recommended. Many higher education institutions have implemented AIS and get benefit on it. However, most of AIS was used for administrative purpose only. In facts, with its ICT capabilities, AIS can support more functionality instead of administrative function.

With the emergence of Education 3.0 paradigm, there are some characteristics in Education 3.0 that can be supported by AIS. There are integrated with e-learning, support parent involvement and support industry involvement. Therefore, the existing AIS must be transformed to support the characteristics. As part of IS, AIS transformation also included in IS/IT management area. In IS management, every improvement process usually need a model as an instrument guide [19].

AIS transformation also needs a model as guidance. A model should be developed based on the internationally recognized standards and the model could be used as an action guideline for HEIs to change their IS [21]. Most of researchers in IS modeling was used case study method and doing interview for collecting data. For integrating technology in education, there is a framework used by some researchers for modeling called Substitution Augmentation Modification Redefinition (SAMR).

\section{REFERENCES}

[1] E. Indrayani, "Management of academic information system (AIS) at higher education in the city of Bandung," Procedia-Social and Behavioral Sciences, vol. 103, pp. 628-636, November 2013.
[2] E. Utami and S. Raharjo, "Database security model in the academic information system," International Journal of Security and Its Applications, vol. 8, pp. 163-174, May 2014.

[3] M. Stevenson, P. Cevenini, I. Temple, R. Halkett, and R. Patton. (2011). Transforming education, transforming lives: A path toward next generation learning. The Cisco Connected Insight Series. [Online]. Available: https://www.cisco.com/web/learning/le21/le34/ downloads/689/educause/whitepaper.pdf

[4] D. Keats and J. P. Schmidt, "The genesis and emergence of Education 3.0 in higher education and its potential for Africa," First Monday, vol. 12, March 2007.

[5] B. A. Alyoubi and M. J. Arif, "A comparative study between the academic information system of King Abdulaziz University and other Saudi Arabia universities," Life Science Journal, vol. 11, pp. 261-275, April 2014.

[6] A. M. Harkins, "Leapfrog principles and practices: Core components of education 3.0 and 4.0," Futures Research Quarterly, vol. 24, pp. 19-31, August 2008.

[7] J. G. Lengel, Education 3.0 Seven Steps to Better School, New York NY, USA: Teacher College Press, January 2013.

[8] D. Light, "Principals for web 2.0 success: 10 ways to build vibrant learning communities with the read/write web," Learning \& Leading with Technology, vol. 39, pp. 18.20, June 2012.

[9] S. Q. Badu, Z. Laisa, A. Dungga, S. Kamuli, and M. I. Nurdin, "Elearning administrative simplification through integration with academic information system of higher education," in Proc. International Symposium on Open, Distance and e-Learning (ISODEL), December 2012.

[10] W. H. Utomo and T. Wellem, "Modeling of business process management of academic affair information system," International Journal of Computer Applications, vol. 64, January 2013.

[11] A. Smith, "Smartphone ownership - 2013 update," Pew Research Center: Washington DC, vol. 12, June 2013.

[12] P. D. Chandler and C. Redman, "Teaching teachers for the future: Modelling and exploring immersive personal learning networks," Australian Educational Computing, vol. 27, pp. 54-62, 2013.

[13] G. H. Lee, A. Z. Talib, W. M. N. W. Zainon, and C. K. Lim, "Learning history using role-playing game (RPG) on mobile platform," Advances in Computer Science and its Applications, vol. 279, Springer Berlin Heidelberg, 2014, pp. 729-734.

[14] R. C. Ho. and H. K. Chua, "The influence of mobile learning on learner's absorptive capacity: A case of Bring-Your-Own-Device (BYOD) learning environment," Taylor's 7th Teaching and Learning Conference 2014 Proceedings, pp. 471-479, 2015.

[15] A. Drigas, R. E. Ioannidou, G. Kokkalia, and M. D. Lytras, "ICTs, mobile learning and social media to enhance learning for attention difficulties," J. UCS, vol. 20, pp. 1499-1510, 2014

[16] N. Borg, J. O'Hara, and C. Hutter, About Edmodo, Edmodo Inc., San Mateo, CA, 2008.

[17] A. Muscio, "University-industry linkages: What are the determinants of distance in collaborations?" Papers in Regional Science, vol. 92, pp. 715-739, 2013.

[18] N. M. Agrawal, M. R. Rao, and S. Venkatesh, "Labour market and recruitment: Education and employability-learning from the Indian IT/ITES industry," India: Preparation for the World of Work, M. Pilz, Ed. Köln, Germany: Springer VS, 2016, pp. 311-329.

[19] J. Becker, R. Knackstedt and J. Pöppelbuß, "Developing maturity models for IT management," Business \& Information Systems Engineering, vol. 1, pp. 213-222, March 2009.

[20] S. A. Mokhtar, S. M. S. Anuar, and S. Puteh, "Information system model for the measurement of learning outcome attainment," in Proc. 4th International Conference on Engineering Technology and Technopreneuship (ICE2T), pp. 37-40, August 2014.

[21] M. Solar, J. Sabattin, and V. Parada, "A maturity model for assessing the use of ICT in school education," Educational Technology \& Society, vol. 16, pp. 206-218, January 2013

[22] D. Pratiwi, "Implementation of function point analysis in measuring the volume estimation of software system in object oriented and structural model of academic system," International Journal of Computer Applications, vol. 70, May 2013.

[23] R. Puentedura. (2010). SAMR and TPCK: Intro to advanced practice. [Online]. Available: http://hippasus.com/resources/sweden2010/ SAMR_TPCK_IntroToAdvancedPractice.pdf

[24] M. Engin and F. Atkinson, "Faculty learning communities: A model for supporting curriculum changes in higher education," International Journal of Teaching and Learning in Higher Education, vol. 27, pp. 164-174, 2015. 
[25] L. T. Jude, M. A. Kajura, and M. P. Birevu, "Adoption of the SAMR model to asses ICT pedagogical adoption: A case of Makerere University," International Journal of e-Education, e-Business, e-Management and e-Learning, vol. 4, pp. 106-115, April 2014.

[26] N. Hockly, "Digital technologies in low-resource ELT contexts," ELT Journal, vol. 68, pp. 79-84, October 2013.

[27] D. Romrell, L. C. Kidder, and E. Wood, "The SAMR model as a framework for evaluating mLearning," Journal of Asynchronous Learning Networks, vol. 18, 2014.

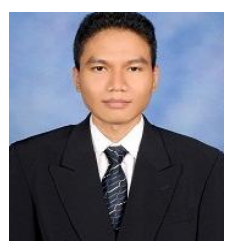

Hadi Prasetyo Utomo is Ph.D student at the Department of Technology Management, Universiti Tun Hussein Onn Malaysia. He was born at Tangerang, Indonesia in 1982. He graduated in information system from the Universitas Komputer Indonesia and has master in digital media from Institute of Technology, Bandung, Indonesia.

He had published more 5 national journals, national and international proceedings. His research interests include software engineering, information system, information and communication technology and technology management.

Mr. Utomo is a member of IAII, APTIKOM and certified in Ethical Hacking.

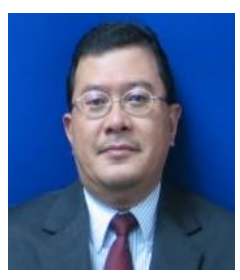

Abdul Talib bin Bon is professor of technology management in the Department of Production and Operations Management at the Universiti Tun Hussein Onn Malaysia. He was born at Kuala Selangor, Selangor, Malaysia on 4 April 1965. He has a $\mathrm{PhD}$ in computer science, which he obtained from the Universite de La Rochelle, France. His doctoral thesis was on topic process quality improvement on beltline moulding manufacturing. He studied business administration in the Universiti Kebangsaan Malaysia for which he was awarded the MBA. He's bachelor degree and diploma in mechanical engineering which his obtained from the Universiti Teknologi Malaysia. He received his postgraduate certificate in mechatronics and robotics from Carlisle, United Kingdom.

He had published more 150 international proceedings and international journals and 8 books. His research interests include manufacturing, forecasting, simulation, optimization, TQM and Green Supply Chain.

Prof. Talib is a member of IEOM, IIE, IIF, TAM, MIM and council member's of MSORSM.

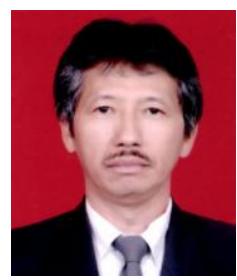

Mokhamad Hendayun is teaching staff of informatics engineering in the Department of Informatics Engineering at the Langlangbuana University Bandung Indonesia. He was born at Bandung, West Java, Indonesia in 11 September 1958. He has a $\mathrm{PhD}$ in computer modeling and simulation, which he obtained from the Technische Universität Berin, Germany. His doctoral thesis was on topic integration of uncertainty analysis method in a dynamic simulation program - Accuracy and computational effort analysis. He's bachelor degree in physics which his obtained from the Institut Teknologi Bandung, Indonesia. He received his postgraduate certificate in process safety analysis of Chemical Plant from Battele Memorial Institue, Frankfurt, Germany.

He had published more 20 international and national proceedings and journals and 5 books. His research interests include software engineering, simulation, security, reliability and safety.

Dr.-Ing. Hendayun is a member of IAII, APTIKOM, HFI, KTG. 